\title{
Spatial variability in distribution and prevalence of Caribbean scleractinian coral and octocoral diseases. I. Community-level analysis
}

\author{
Ernesto Weil*, Aldo Cróquer \\ Dept. of Marine Sciences, University of Puerto Rico, PO Box 908, Lajas 00667, Puerto Rico
}

\begin{abstract}
Geographic assessments of coral diseases are needed to understand their local and geographic spatial-temporal variability. Coral and octocoral diseases and their prevalence were assessed along 4 permanent $10 \times 2 \mathrm{~m}$ band-transects in each of 3 depth habitats $(<4,5-12$ and $>15 \mathrm{~m})$ in each of 2 reefs in each of 6 countries across the wider Caribbean during the summer and fall of 2005. A permutational multivariate analysis of variance was used to test variability of major diseases and community level disease prevalence in corals and octocorals among habitats, reefs and countries. The most common and damaging diseases reported for the region were found in most reefs surveyed, but prevalence at the community level was generally low (ca. $2 \%$ ) increasing from northern to southern latitudes. A significant interaction between sites (nested within country) and depth habitats was found $(F=2.1$, df $=12, \mathrm{p}=0.02)$, with higher prevalence of coral diseases in deep habitats of Culebrita, Puerto Rico (14.8 \pm SE 6.5\%) and in shallow habitats of Roldán, Panamá (10.2 \pm SE 3.5\%). The relative importance of each particular disease was dependent on site and habitat (depth intervals) $(F=1.7, \mathrm{df}=12, \mathrm{p}=0.001)$, with black band disease more prevalent in shallow habitats of Rita's, Bermuda (1.7 \pm SE $0.4 \%$ ) and yellow band disease (YBD) more prevalent in deeper habitats of Chub Cut, Bermuda $(3.7 \pm$ SE $0.5 \%)$. There was a significant interaction of total octocoral diseases with country and habitat $(F=2.8, \mathrm{df}=10, \mathrm{p}=0.04)$ with higher prevalence in deeper habitats of Curaçao $(25.9 \pm \mathrm{SE} 4.2 \%)$. Our results indicate that patterns of prevalence of coral and octocoral diseases were not consistent across the different spatial scales, showing differences produced by particular diseases and community composition present. There were no widespread epizootics, but local white plague-II and YBD epizootics were observed in Puerto Rico and other localities.
\end{abstract}

KEY WORDS: Coral diseases · Caribbean · Octocoral diseases · Spatial variability · Prevalence

\section{INTRODUCTION}

Marine epizootics have been impacting populations of sea turtles, mollusks, marine mammals, echinoderms and coral reef organisms over the last 3 decades (McCallum et al. 2003, Ward \& Lafferty 2004), in some cases significantly reducing population sizes. Infectious diseases affecting major reef-building scleractinian coral species and other important biological groups (e.g. crustose coralline algae, sponges, octocorals, zoanthids, hydrocorals) are regarded as the most important factor contributing to the lost of live cover and population declines, and therefore, the recent deterioration of these important tropical marine communities (Weil 2004, Willis et al. 2004, Ballantine et al. 2005, Bruckner \& Bruckner 2006, Weil et al. 2006). In the Caribbean, the number of new syndromes affecting scleractinian corals, octocorals and other reef organisms, and their distribution, virulence, prevalence and epizootics, have been increasing in the last decades, hence, the 'disease hot spot' characterization of the region (Harvell et al. 1999, 2007, Green \& Bruckner 2000, Aronson \& Precht 2001, Weil et al. 2002, Sutherland et al. 2004, Weil 2004). 
Bleaching events have also been increasing in frequency and intensity (Williams \& Bunkley-Williams 1990, Cortés 2003, McClanahan et al. 2009), and the 2005 bleaching event was the worse in recent times, affecting most zooxanthellated reef groups (e.g. corals, octocorals, hydrocorals, zoanthids, sponges, anemones), some of which remained bleached for a prolonged period of time ( $>6$ mo depending on geographical location). Increased water temperatures and bleaching events might have facilitated the rapid emergence and impact of diseases in the region (Aronson et al. 2002, Harvell et al. 2002, 2007) by affecting resistance of host, virulence of pathogens, or combinations of these and/or other factors (Weil 2004).

Despite this rapid emergence and impact of diseases on coral reef ecosystems (e.g. the widespread epizootics that affected the acroporids Acropora palmata and A. cervicornis, the black sea urchin Diadema antillarum, and the octocoral Gorgonia ventalina), their etiology (causal agents), pathology (signs and physiological effects and mechanism producing host mortality) and their epizootiology (prevalence, incidence and rate of spread in natural populations) remain poorly understood (Richardson 1998, Sutherland et al. 2004, Weil et al. 2006). Even though localized human impacts (e.g. eutrophication, sedimentation) and global warming seem to promote epizootics as they could compromise host resistance and enhance virulence of pathogens (Harvell et al. 2002, Bruno et al. 2003, Kaczmarsky et al. 2005), lack of baseline data for marine organisms, including corals, makes it difficult to understand the immediate causes that trigger epizootic events and overall impacts, hindering the development of efficient and effective managing plans for this problem (Ward \& Lafferty 2004). Lack of barriers in open marine ecosystems and the transoceanic transport of ballast waters might facilitate the spread of marine diseases (McCallum et al. 2003, Ward \& Lafferty 2004, Weil 2004). Yet it remains unclear what is causing the sudden emergence of so many marine and coral diseases and why they are spreading so fast.

With the exception of the Caribbean-wide surveys of Weil et al. (2002), and the AGGRA and AIMS disease monitoring programs (Lang 2003, Willis et al. 2004), most ecological coral disease studies have focused on determining prevalence and impact at small spatial scales. Weil et al. (2002) showed that coral diseases are widespread across the Caribbean affecting major reef builders, thereby presenting a potential primary cause to the reef degradation trend in the region and a threat to their future. This work also showed increasing disease prevalence with decreasing latitude, from Bermuda down to Venezuela. Based on what is currently known about marine diseases and what approaches have been useful in land ecosystems, for both humans and wildlife, Ward \& Lafferty (2004) suggested 5 research priorities to better address the problem of marine diseases: (1) develop molecular and microbiological diagnostics and the capability to identify and track particular pathogen types to trace origins and spread of marine pathogens; (2) develop rapid response capabilities to identify, monitor, and manage disease outbreaks as they occur; (3) document longevity and host range of infectious stages; (4) pinpoint the facilitating role of the environment in disease outbreaks; and (5) develop forecasting models for outbreaks that are sensitive to environmental or climatic factors.

Fulfilling these research priorities for diseases affecting corals and octocorals in the Caribbean requires the collection of more baseline data on disease distribution, prevalence, incidence and impact at different biological (individual colonies, populations and communities), spatial (habitats, reefs, countries, regions) and temporal (seasonal, yearly, decadal) scales. Such information will complement the data currently being gathered on geographic distributions, host range, putative pathogens, vectors and reservoirs, which will then help to better understand the origin, etiology, epizootiology and spatial and temporal dynamics of the most important diseases affecting reef organisms today (Richardson et al. 2001, Weil et al. 2002, Sutherland et al. 2004, Weil 2004) and, perhaps, provide answers as to how to prevent, treat and manage this problem.

Characterizing reef sites where disease distribution and prevalence, and the frequency, intensity and distribution of epizootic events, is different from other reefs might provide important information to better understand the spatial/temporal dynamics of coral and octocoral diseases in the region. The present study complements the work started in 1999 by Weil et al. (2002) and provides an opportunity to compare the status of some reefs $6 \mathrm{yr}$ after the initial surveys were done, as part of a long-term monitoring program to assess the status and the spatial and temporal variability in the number, distribution, prevalence, host range and impact (populations and communities) of coral and octocoral diseases across the Caribbean. Our goals in the present study were to (1) assess the current status and variability in the number of diseases and the prevalence of the major diseases (black band disease [BBD], white plague type II [WP-II], yellow band disease [YBD], dark spots disease [DSD], aspergillosis [ASP]) at various spatial scales (habitats, reefs, reef within countries and countries across wide geographic regions), (2) assess what factors could be producing this variability, if any, and (3) increase the number of replicate reefs within each country and continue with monitoring to assess changes through time. 


\section{MATERIALS AND METHODS}

Disease surveys and sampling design. Surveys were conducted from late August to early December 2005 (i.e. over ca. $3 \mathrm{mo}$ ), to include the season of higher temperatures and usually higher number and prevalence of most coral and octocoral diseases, and to avoid seasonal variability. Prevalence of diseases affecting corals and octocorals was assessed on 12 reefs distributed across the Caribbean and northwest Atlantic region (Fig. 1, Table 1). In the southern Caribbean, surveys were conducted in Grenada, Curaçao and Panamá following an east-to-west geographic transect. Surveys were performed in Puerto Rico and Grand Cayman in the northern Caribbean and Bermuda in the northwest Atlantic. Bermuda is in the northernmost distribution of coral reefs in the Caribbean-Atlantic, under different environmental regimes, and is an important locality to consider when assessing the geographic variability in distribution and prevalence of coral reef diseases.

Four haphazardly placed belt-transects $(10 \times 2 \mathrm{~m}=$ $20 \mathrm{~m}^{2}$ ) were permanently marked with rebars and numbered tags in each of 3 depth intervals: shallow $(<4 \mathrm{~m})$, intermediate $(5-12 \mathrm{~m})$ and deep $(>15 \mathrm{~m})$ in each of 6 geographically distant countries to assess the spatial and temporal variability in number, distribution and prevalence of major diseases affecting corals, octocorals and other reef organisms. The general CARICOMP disease protocol was used (Weil et al. 2002) to estimate disease prevalence. In each bandtransect, all diseased and healthy colonies of corals and octocorals were examined and counted, moving two $1 \mathrm{~m}$ long PVC rods along each side of the transect line to standardize the sampling area of each bandtransect. Each physically independent colony or ramet was considered as an individual, except for those close ramets clearly resulting from the collapse of a columnar or thick branched species (e.g. Montastraea annularis, Porites porites, Dendrogyra cylindrus). Coral species and disease/syndrome identifications were standardized and double checked in situ, and when in doubt, colonies were photographed and checked against photographic guides and the literature. Average total disease (all diseases and all coral species) prevalence for the coral community in each habitat (depth interval) was quantified as the average total disease prevalence of the 4 replicate band-transects. Disease prevalence in each band-transect was estimated by dividing the number of all diseased coral colonies over all the coral colonies counted in that transect. The average total disease prevalence for a reef was calculated by averaging the prevalence of all 12 band-transects. Estimates for the total prevalence of

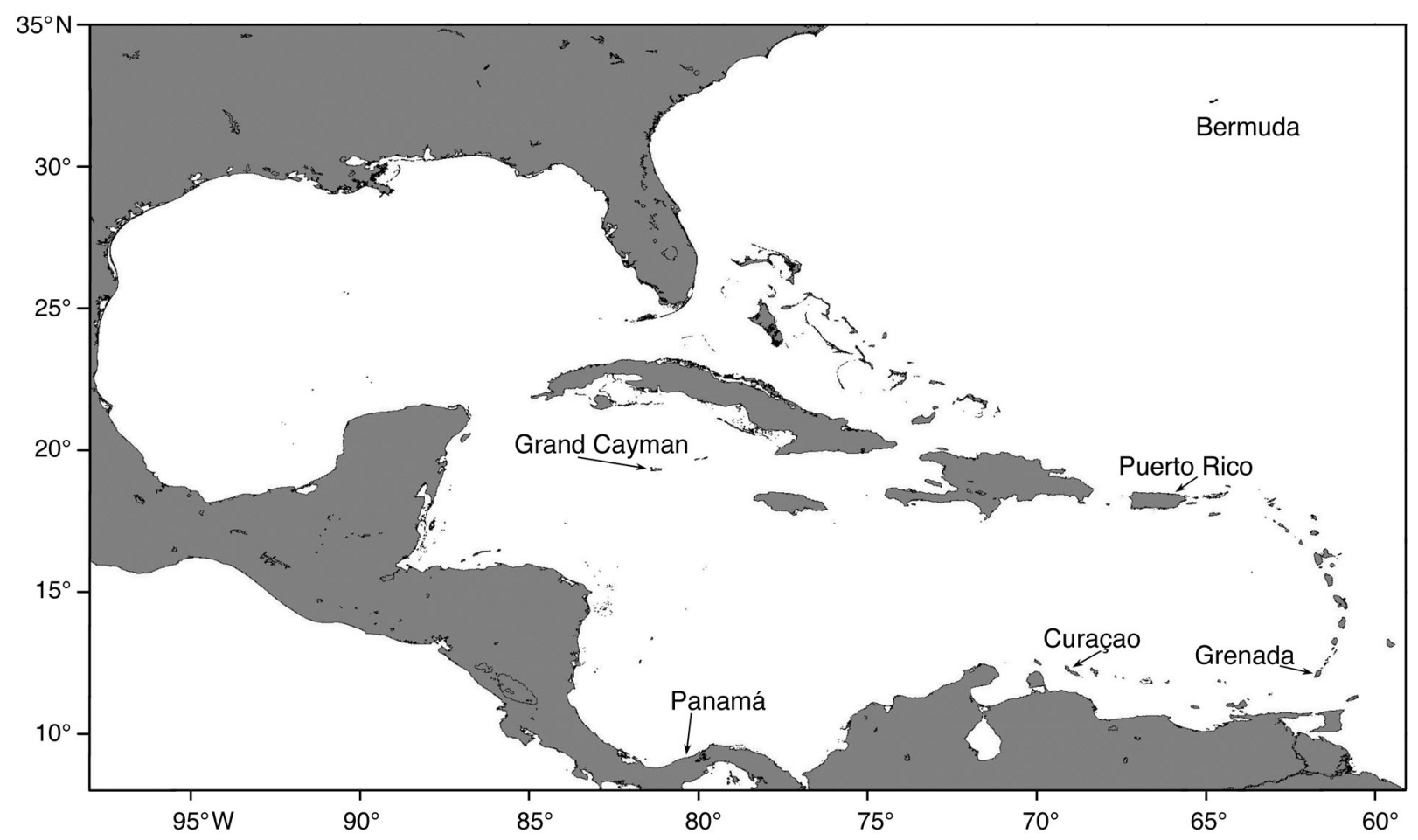

Fig. 1. Wider Caribbean region showing survey locations. Two reefs were surveyed in each location, using 3 depth habitats $(<4,5-12,>15 \mathrm{~m})$ and 4 transects at each depth 
Table 1. Geographic coordinates, general characteristics and total number of colonies surveyed in 12 reefs across the wider Caribbean in 2005. Country and site abbreviations (abbrev.) are used in subsequent Tables and Figures (also in Cróquer \& Weil 2009, this issue)

\begin{tabular}{|c|c|c|c|c|c|}
\hline Country (abbrev.) & Reef (abbrev.) & Location & Reef type & $\begin{array}{l}\text { Max. depth } \\
(\mathrm{m})\end{array}$ & $\begin{array}{c}\text { No. of } \\
\text { colonies }\end{array}$ \\
\hline \multirow[t]{2}{*}{ Bermuda (BER) } & Rita (RIT) & $32^{\circ} 21.48^{\prime} \mathrm{N}, 64^{\circ} 38.49^{\prime} \mathrm{W}$ & Fringing & 22 & 4326 \\
\hline & Chub Cut (CHC) & $32^{\circ} 20.82^{\prime} \mathrm{N}, 64^{\circ} 55.67^{\prime} \mathrm{W}$ & Patch & 17 & 2880 \\
\hline \multirow[t]{2}{*}{ Puerto Rico (PRT) } & Guánica (GUA) & $17^{\circ} 58.36^{\prime} \mathrm{N}, 66^{\circ} 47.29^{\prime} \mathrm{W}$ & Fringing & 20 & 987 \\
\hline & Culebrita (CUL) & $18^{\circ} 19.07^{\prime} \mathrm{N}, 65^{\circ} 13.49^{\prime} \mathrm{W}$ & Fringing & 14 & 1865 \\
\hline \multirow[t]{2}{*}{ Curaçao (CUR) } & Sea Aquarium (SAQ) & $12^{\circ} 05.04^{\prime} \mathrm{N}, 68^{\circ} 53.69^{\prime} \mathrm{W}$ & Fringing & 45 & 2069 \\
\hline & Habitat Hotel (HAB) & $12^{\circ} 11.90^{\prime} \mathrm{N}, 69^{\circ} 04.73^{\prime} \mathrm{W}$ & Fringing & 45 & 2572 \\
\hline \multirow[t]{2}{*}{ Grenada (GRN) } & Flamingo Bay (FLM) & $12^{\circ} 05.52^{\prime} \mathrm{N}, 61^{\circ} 45.54^{\prime} \mathrm{W}$ & Fringing & 25 & 3692 \\
\hline & Valleys (VAL) & $12^{\circ} 01.62^{\prime} \mathrm{N}, 61^{\circ} 47.06^{\prime} \mathrm{W}$ & Fringing & 25 & 4216 \\
\hline \multirow[t]{2}{*}{ Grand Cayman (CAY) } & Andes Wall (AND) & $19^{\circ} 21.83^{\prime} \mathrm{N}, 81^{\circ} 15.24^{\prime} \mathrm{W}$ & Spur + groove & 22 & 1874 \\
\hline & South Point (SPO) & $19^{\circ} 15.79^{\prime} \mathrm{N}, 81^{\circ} 23.01^{\prime} \mathrm{W}$ & Spur + groove & 17 & 2274 \\
\hline \multirow[t]{2}{*}{ Panamá (PAN) } & Isla Colón (STRI) & $09^{\circ} 20.06^{\prime} \mathrm{N}, 82^{\circ} 15.05^{\prime} \mathrm{W}$ & Fringing & 17 & 3361 \\
\hline & Cayo Roldán (ROL) & $09^{\circ} 13.01^{\prime} \mathrm{N}, 82^{\circ} 19.03^{\prime} \mathrm{W}$ & Fringing & 15 & 8337 \\
\hline
\end{tabular}

each particular disease at the community level was done in the same way but only the numbers of colonies affected by a specific disease were considered. Similar procedures were used for the octocorals.

Statistical analysis. To assess the variability in disease prevalence at different spatial scales, a 3-factor design was used (Factor 1: Country, crossed and fixed with 6 levels; Factor 2: Reef site, nested within Factor 1 and random with 2 levels; Factor 3: Depth habitat, crossed and fixed with 3 levels) (Underwood 1999). Thus, total coral and octocoral disease prevalence was compared across Bermuda (Rita's and Chub Cut), Grand Cayman (Andes Wall and South Point), Puerto Rico (Guánica and Culebrita), Grenada (Flamingo Bay and Valleys), Curaçao (Sea Aquarium and Habitat Hotel) and Panamá (Isla Colón and Cayo Roldán).

Because the data did not fulfill multivariate analysis of variance assumptions (i.e. homogeneity of variances and normality, cf. Underwood 1999), a permutational multivariate analysis of variance (PERMANOVA) based on Euclidean distances (Anderson 2001) was used to test whether total disease prevalence (for coral and octocorals) varied among depths, sites and countries. The same analysis was repeated to assess the variability of particular coral and octocoral diseases among depths sites and countries, but based on BrayCurtis similarity index (Anderson 2001). In both cases, pair-wise post hoc comparisons based on permutations were performed among factors with statistical significance. A non-metric multidimensional scaling (NMDS) was used to detect spatial patterns of prevalence of each particular disease and their contribution to average dissimilarity (SIMPER) wherever statistical differences were found. Data was $\log (x+1)$-transformed to prevent weighting of the more prevalent diseases in the ordination (Clarke \& Warwick 2001). This report presents community-level results (commonly found in the literature), and genera-level results are presented in Cróquer \& Weil (2009, this issue); these 2 approaches provide different perspectives on the same problem.

Table 2. Three factorial univariate PERMANOVA based on Euclidean distance for total disease prevalence (sum of all diseases recorded over each replicate, $\mathrm{N}=144$ ). Factor 1: Country, crossed and fixed; Factor 2: Reef site, nested within Factor 1 and random; Factor 3: Depth habitat, crossed and fixed. Bold indicates significant source of variation

\begin{tabular}{|c|c|c|c|c|c|}
\hline Source & $\mathrm{df}$ & SS & MS & $F$ & $\mathrm{p}$ \\
\hline Country & 5 & 473.19 & 94.64 & 1.4397 & 0.259 \\
\hline Site(Country) & 6 & 394.42 & 65.74 & 4.2774 & 0.002 \\
\hline Depth & 2 & 7.13 & 3.57 & 0.111 & 0.89 \\
\hline Country $\times$ Depth & 10 & 278.55 & 27.86 & 0.867 & 0.603 \\
\hline Site $($ Country $) \times$ Depth & 12 & 385.53 & 32.13 & 2.0905 & 0.031 \\
\hline Residual & 108 & 1659.78 & 15.37 & & \\
\hline Total & 143 & 3198.61 & & & \\
\hline
\end{tabular}




\section{RESULTS}

\section{Prevalence and geographic range of distribution of scleractinian diseases}

Total prevalence of coral diseases was generally low, from $2.9 \pm 3.1 \%$ in Bermuda to $4.3 \pm 5.9 \%$ and $3.8 \pm$ $4.2 \%$ in countries in the northern and southern Caribbean regions, respectively, although no significant differences were found (Table 2). Reef sites (nested within Country) $\times$ Depth habitat interaction was statistically significant (PERMANOVA, $F=2.1$, $\mathrm{df}=12, \mathrm{p}=0.02$ ), with higher prevalence of coral diseases in deep habitats of Culebrita, Puerto Rico (14.8 \pm SE $6.5 \%$ ) and in shallow habitats of Cayo Roldán, Panamá (10.2 \pm SE 3.5\%) (Table 2, Fig. 2).

The prevalence of each particular disease was also dependent on reef sites and habitats (PERMANOVA, $F=$ 1.7, $\mathrm{df}=12, \mathrm{p}=0.001$, Table 3). BBD, YBD, WP-II and DSD significantly varied among reef sites (differences explained by habitats; Table 4). BBD was more prevalent in the shallow habitats of Rita's (Bermuda) $(1.7 \pm \mathrm{SE}$ $0.4 \%$ ) and YBD was more prevalent in the deep habitats of Sea Aquarium (Curaçao) (4.8 \pm SE 0.5\%) and Chub Cut (Bermuda) (3.7 \pm SE 0.5\%) (Fig. 3a,b). Levels of prevalence of WP-II were low $(<1 \%)$; the only exceptions were the deep $(14.7 \pm$ SE $1.5 \%)$ and intermediate $(7.01 \pm$ SE $1.5 \%$ ) habitats of Culebrita in Puerto Rico and the shallow habitat of Cayo Roldán in Panamá (Fig. 3c). Prevalence of DSD was above $1 \%$ only in deeper habitats of reefs in Curaçao and Grenada (Fig. 3d).

Other diseases/syndromes showed relatively low prevalence across reefs, countries and regions. For instance, Caribbean ciliate infection (CCI), a new problem recently described and produced by the protozoan Halofolliculina sp. (Cróquer et al. 2006a), was geographically restricted in its distribution to Curaçao and Panamá compared to microbial diseases. Ciliates were especially abundant in coral colonies infected with other diseases such as YBD and WP-II at intermediate transects of Habitat Hotel, Curaçao (5 \pm SE $0.5 \%)$ and Isla Colón, Panamá (2.3 \pm SE 0.5\%). White syndromes, growth anomalies (GAN) and compromised-health problems were widespread across the wider Caribbean, but with low prevalence $(<1 \%)$, mostly in shallow and intermediate habitats. Another recent problem, colonies bearing multiple diseases/syndromes (i.e. MULTI = WPD-II, YBD, CCI, DSD and/or BBD), were often observed in colonies in all depth habitats of many reefs surveyed.
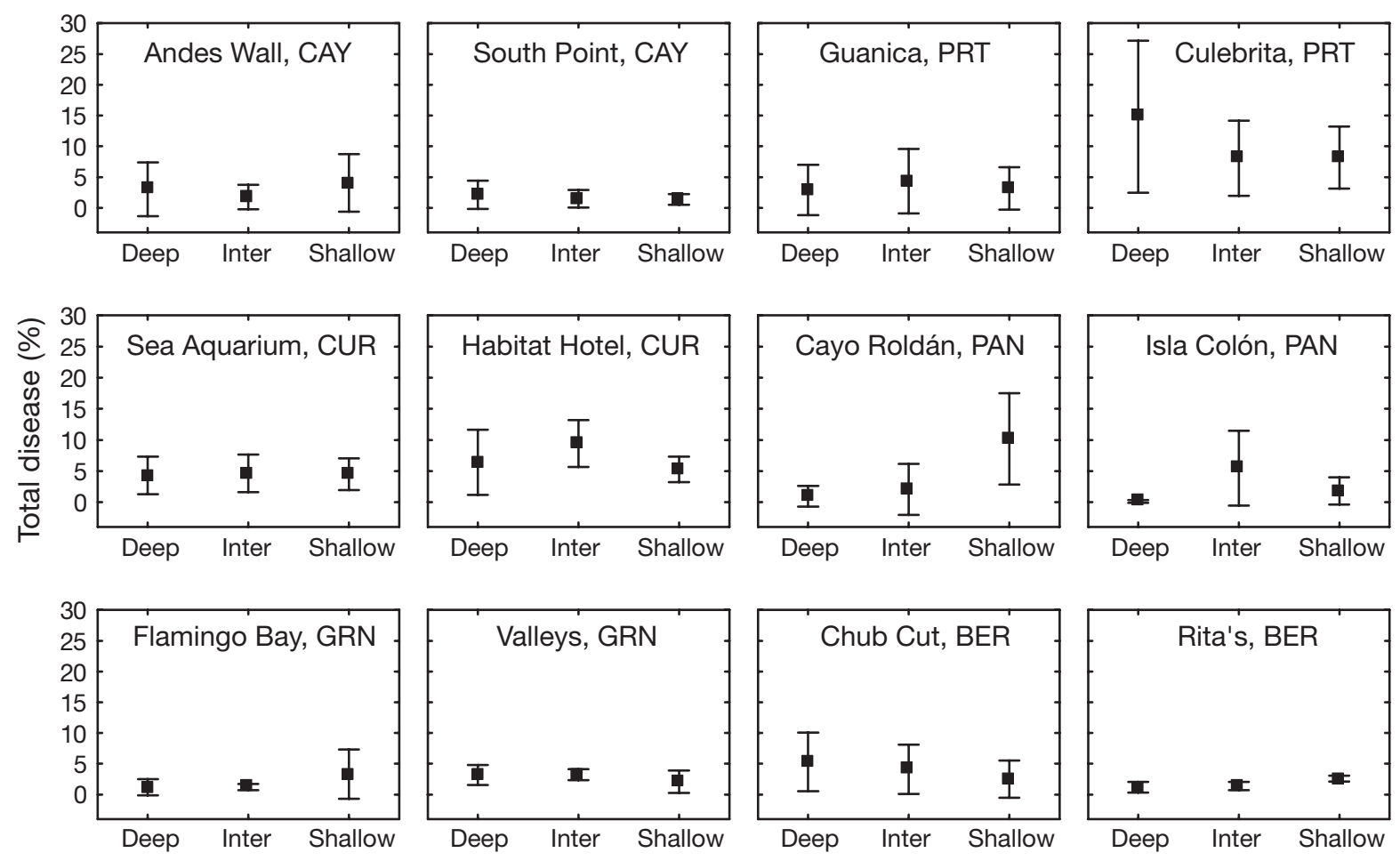

Habitats

Fig. 2. Average $( \pm \mathrm{SD})$ total disease prevalence for scleractinian corals along the depth-related habitats $(\mathrm{deep},>15 \mathrm{~m} ;$ inter [mediate], 5-12 $\mathrm{m} ;$ shallow, $<4 \mathrm{~m}$ ) in each reef surveyed. Country abbreviations as in Table 1 
Table 3. Three factorial multivariate PERMANOVA based on Bray-Curtis similarity for the prevalence of 11 coral diseases (black band disease, white plague, yellow band disease, dark spots disease, white band disease, patchy 'necrosis', Caribbean ciliate infection, multi-disease, growth anomalies and other health problems) found at $\mathrm{N}=144$ belt-transects. Design as in Table 2 . Bold indicates significant source of variation

\begin{tabular}{|c|c|c|c|c|c|}
\hline Source & $\mathrm{df}$ & SS & MS & $F$ & $\mathrm{p}$ \\
\hline Country & 5 & 82251.99 & 16450.40 & 3.3707 & 0.002 \\
\hline Site(Country) & 6 & 29282.87 & 4880.48 & 2.1767 & 0.001 \\
\hline Depth & 2 & 18370.23 & 9185.11 & 2.3895 & 0.015 \\
\hline Country $\times$ Depth & 10 & 40179.97 & 4018.00 & 1.0453 & 0.417 \\
\hline Site $($ Country $) \times$ Depth & 12 & 46126.45 & 3843.87 & 1.7144 & 0.001 \\
\hline Residual & 108 & 242151.38 & 2242.14 & & \\
\hline Total & 143 & 458362.89 & & & \\
\hline
\end{tabular}

\section{Prevalence and range of distribution of octocoral diseases}

The overall prevalence of octocoral diseases (i.e. sum of aspergillosis, growth anomalies and other compromise-health problems) were significantly higher compared to scleractinian corals, and varied significantly across country and habitat (PERMANOVA, $F=2.8 \mathrm{df}=$ $10, p=0.04$, Table 5). Higher values of octocoral diseases were found in the shallower habitats of Grenada $(26.2 \pm$ SE $4.2 \%)$, Bermuda (21.8 \pm SE $4.2 \%)$ and Grand
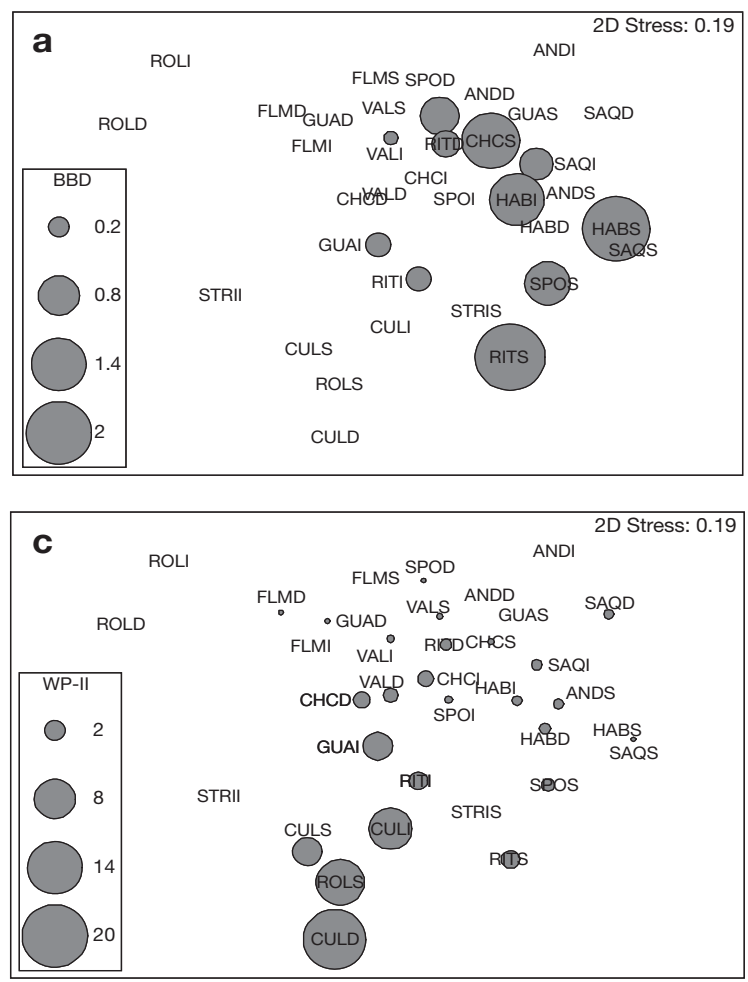

Cayman (20.5 \pm SE 4.2\%) (Fig. 4). High prevalence levels in deeper habitats were only found in Curaçao $(25.9 \pm$ SE $4.2 \%)$ (Fig. 4, Table 6). The country $\times$ Depth habitat interaction was statistically significant (PERMANOVA, $F=1.7, \mathrm{df}=12, \mathrm{p}=0.009$ ) when the prevalence of each of the different octocoral diseases was compared (Table 7). Aspergillosis (ASP) was significantly more prevalent in the shallower habitats of Grenada (12.3 \pm SE $2.7 \%)$ and in the deeper habitats of Curaçao $(10.8 \pm$ SE $2.7 \%$ ) (Fig. 5a). While the shallower habitats of Bermuda were characterized by high
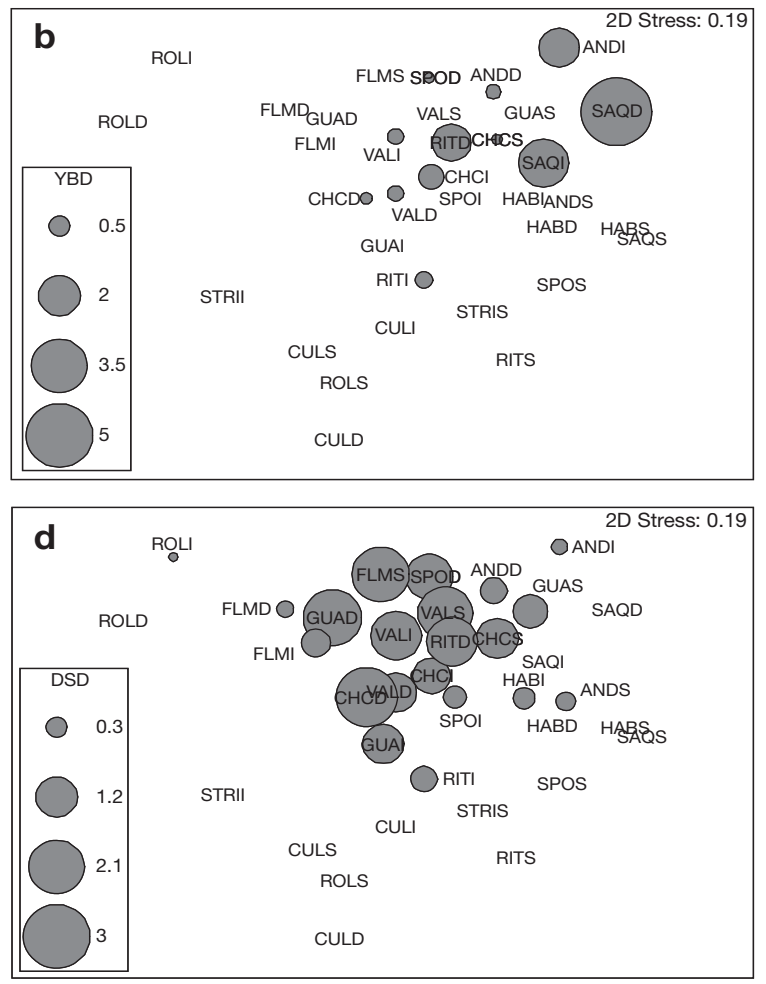

Fig. 3. Non-metric multidimensional diagram (NMDS) based on Bray-Curtis dissimilarities showing mean prevalence (log[ $x+1])$ of major coral diseases: (a) black band disease (BBD), (b) yellow band disease (YBD), (c) white plague type II (WP-II) and (d) dark spot disease (DSD). Bubbles represent the mean percentage of prevalence. Site abbreviations as in Table 1, suffixed with the depth-related habitat $(\mathrm{S}=$ shallow, $\mathrm{I}=$ intermediate, $\mathrm{D}=$ deep) (e.g. ROLD = Cayo Roldán, Deep) 
Table 4. SIMPER showing dissimilarities (Bray-Curtis) between significantly different sites $\times$ depth habitats (permutational test, $\mathrm{p}<0.01$ ) and the coral diseases that better explained these differences (DSD: dark spots disease; YBD: yellow band disease; PRED: predation; BBD: black band disease; WP-II: white plague type II; MULTI: multiple conditions in a single colony; CCI: Caribbean ciliate infection; OTH: other undescribed compromised-health conditions). Gray scale indicates degree of dissimilarity: $50-80 \%$ (light gray), 80-95\% (intermediate gray) and 95-100\% (dark gray). Site abbreviations as in Table 1. Depth habitats: deep (D, >15 m), intermediate (I, 5-12 m), shallow $(\mathrm{S},<4 \mathrm{~m})$

\begin{tabular}{|c|c|c|c|c|c|c|c|c|c|c|c|c|c|}
\hline Site & Habitat & AND & $\mathrm{SPO}$ & GUA & CUL & SAQ & HAB & ROL & STRI & FLM & VAL & $\mathrm{CHC}$ & RIT \\
\hline & & D I S & $\begin{array}{lll}D & \mathrm{I}\end{array}$ & D I $S$ & D I S & D I S & D I S & D I S & D I S & D I $S$ & D I S & D I S & D I $\mathrm{S}$ \\
\hline AND & $\begin{array}{l}\mathrm{D}(\mathrm{DSD}) \\
\mathrm{I}(\mathrm{YBD}) \\
\mathrm{S}(\mathrm{PRED})\end{array}$ & & & & & & & & & & & & \\
\hline SPO & $\begin{array}{l}\text { D(PRED) } \\
\text { I(DSD) } \\
\text { S(BBD) }\end{array}$ & & & & & & & & & & & & \\
\hline GUA & $\begin{array}{l}\text { D(DSD) } \\
\text { I(DSD) } \\
\text { S(PRED) }\end{array}$ & & & & & & & & & & & & \\
\hline CUL & $\begin{array}{l}\text { D(WP-II) } \\
\text { I(WP-II) } \\
\text { S(MULTI) }\end{array}$ & & & & & & & & & & & & \\
\hline SAQ & $\begin{array}{l}\mathrm{D}(\mathrm{YBD}) \\
\mathrm{I}(\mathrm{YBD}) \\
\mathrm{S}(\mathrm{PRED})\end{array}$ & & & & & & & & & & & & \\
\hline HAB & $\begin{array}{l}\text { D(WP-II) } \\
\text { I(BBD) } \\
\text { S(PRED) }\end{array}$ & & & & & & & & & & & & \\
\hline ROL & $\begin{array}{l}\mathrm{D} \text { (PRED) } \\
\mathrm{I}(\mathrm{CCI}) \\
\mathrm{S}(\mathrm{WP}-\mathrm{II})\end{array}$ & & & & & & & & & & & & \\
\hline STRI & $\begin{array}{l}\mathrm{D}(\mathrm{OTH}) \\
\mathrm{I}(\mathrm{CCI}) \\
\mathrm{S}(\mathrm{MULTI})\end{array}$ & & & & & & & & & & & & \\
\hline FLM & $\begin{array}{l}\text { D(MULTI } \\
\text { I(DSD) } \\
\text { S(MULTI) }\end{array}$ & & & & & & & & & & & & \\
\hline VAL & $\begin{array}{l}\mathrm{D}(\mathrm{DSD}) \\
\mathrm{I}(\mathrm{DSD}) \\
\text { S(DSD) }\end{array}$ & & & & & & & & & & & & \\
\hline $\mathrm{CHC}$ & $\begin{array}{l}\mathrm{D}(\mathrm{YBD}) \\
\mathrm{I}(\mathrm{YBD}) \\
\mathrm{S}(\mathrm{BBD})\end{array}$ & & & & & & & & & & & & \\
\hline RIT & $\begin{array}{l}\mathrm{D}(\mathrm{BBD}) \\
\mathrm{I}(\mathrm{BBD}) \\
\mathrm{S}(\mathrm{BBD}) \\
\end{array}$ & & & & & & & & & & & & \\
\hline
\end{tabular}

Table 5. Three factorial univariate PERMANOVA based on Euclidean distance for the prevalence of total octocoral diseases (sum of all octocoral diseases) found at $\mathrm{N}=144$ belt-transects. Design as in Tables $2 \& 3$. Bold indicates significant source of variation

\begin{tabular}{|lrrrrr|}
\hline Source & df & \multicolumn{1}{c|}{ SS } & MS & F & p \\
\hline Country & 5 & 24.52 & 4.90 & 1.4504 & 0.248 \\
Site(Country) & $\mathbf{6}$ & $\mathbf{2 0 . 2 9}$ & $\mathbf{3 . 3 8}$ & $\mathbf{2 . 3 6 3 8}$ & $\mathbf{0 . 0 2 8}$ \\
Depth & 2 & 6.25 & 3.12 & $\mathbf{2 . 8 2 5 4}$ & 0.249 \\
Country $\times$ Depth & $\mathbf{1 0}$ & $\mathbf{5 9 . 3 0}$ & $\mathbf{5 . 9 3}$ & $\mathbf{0 . 0 4 5}$ \\
Site(Country) $\times$ Depth & 12 & 25.19 & 2.10 & & 0.125 \\
Residual & 108 & 154.49 & 1.43 & \\
Total & 143 & 290.03 & & \\
\hline
\end{tabular}



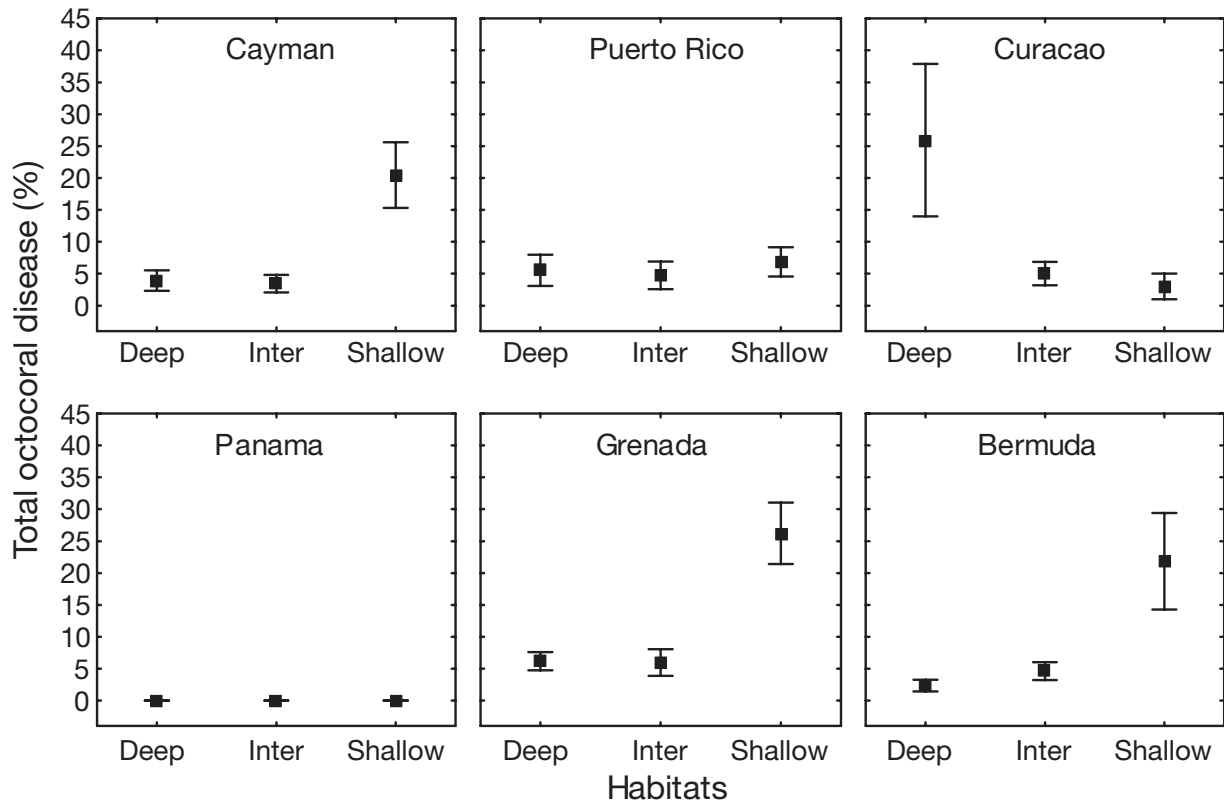

Fig. 4. Average $( \pm \mathrm{SD})$ total disease prevalence for octocorals along the depth-related habitats (deep, $>15 \mathrm{~m}$; inter[mediate], 5-12 $\mathrm{m}$; shallow, <4 m) for each of the 6 geographic locations (countries)

levels of prevalence of other undescribed syndromes affecting octocorals $(25.5 \pm$ SE $3.5 \%)$, deeper habitats in Bermuda and Puerto Rico, and intermediate and shallow habitats in Grand Cayman and Curaçao showed lower levels of prevalence of these syndromes (Fig. 5b). Growth anomalies were significantly more prevalent in the shallower habitats of Grenada (5.1 \pm SE $0.9 \%)$ and Cayman $(1.6 \pm$ SE $0.9 \%)$; and in the intermediate $(2.9 \pm$ SE $0.9 \%)$ and deeper habitats $(1.3$ \pm SE $0.9 \%$ ) (Fig. 5c, Table 7).

\section{DISCUSSION}

Results confirmed the wide-spread distribution of coral and octocoral diseases across the wider Caribbean and the generally low, but highly variable, mean total disease prevalence previously reported at geo- graphic (Weil et al. 2002), and local scales in Venezuela (Cróquer et al. 2003, García et al. 2003), the Florida Keys (Santavy et al. 2005) and Mexico (Ward et al. 2006). Average community-level disease prevalence rarely exceeded $6 \%$, similar to values reported by Weil et al. (2002) after surveying 19 reef sites in 6 geographically distant localities of the wider Caribbean during the same period (summer and fall) in 1999. Even though a similar increasing trend in disease prevalence from northern (Bermuda) to southern latitudes was observed in this study, no significant differences across the latitudinal gradient were found. Even with the low reef replication within country and region, the consistency of the prevalence values and the number of diseases across geographic localities in 1999 and 2005, and with other reports, suggest that prevalence values between 1 and $6 \%$ might reflect today's 'normal or background' average disease preva-

Table 6. Three factorial multivariate PERMANOVA for the prevalence of 3 octocoral diseases (aspergillosis, growth anomalies and other undescribed syndromes) found at $\mathrm{N}=144$ belt-transects. Design as in Tables 2, 3 \& 5. Bold indicates significant source of variation

\begin{tabular}{|lrrrrr|}
\hline Source & df & \multicolumn{1}{c|}{ SS } & MS & F \\
\hline Country & $\mathbf{5}$ & $\mathbf{7 6 9 5 0 . 5 7}$ & $\mathbf{1 5 3 9 0 . 1 1}$ & $\mathbf{3 . 7 0 5 9}$ & $\mathbf{0 . 0 3 9}$ \\
Site(Country) & $\mathbf{6}$ & $\mathbf{2 4 9 1 7 . 3 8}$ & $\mathbf{4 1 5 2 . 9 0}$ & $\mathbf{1 . 7 1 3 8}$ & $\mathbf{0 . 0 4 1}$ \\
Depth & 2 & 7303.42 & 3651.71 & 0.8703 & 0.507 \\
Country $\times$ Depth & 10 & 61601.47 & 6160.15 & 1.468 & 0.195 \\
Site(Country) $\times$ Depth & $\mathbf{1 2}$ & $\mathbf{5 0 3 5 3 . 7 9}$ & $\mathbf{4 1 9 6 . 1 5}$ & $\mathbf{1 . 7 3 1 6}$ & $\mathbf{0 . 0 0 9}$ \\
Residual & 108 & 261713.05 & 2423.27 & & \\
Total & 143 & 482839.68 & & & \\
\hline
\end{tabular}


Table 7. Percentage similarity analysis (SIMPER) showing Bray-Curtis percentage similarities between sites $\times$ depths significantly different and the octocoral diseases that better explained these differences (OTH: uncharacterised adverse-health conditions; GAN: growth anomalies; ASP: aspergillosis). Gray scale indicates degree of dissimilarity: 50-80\% (light gray), 80-95\% (intermediate gray) and 95-100\% (dark gray). Depth habitats: deep (D, >15 m), intermediate (I, 5-12 m), shallow ( $\mathrm{S},<4 \mathrm{~m})$. ${ }^{*}$ No octocoral was found in the Panamá reefs

\begin{tabular}{|c|c|c|c|c|c|c|c|c|c|c|c|c|c|c|c|c|c|c|c|}
\hline Country & Habitat & \multicolumn{3}{|c|}{ Cayman } & \multicolumn{3}{|c|}{ Puerto Rico } & \multicolumn{3}{|c|}{ Curaçao } & \multicolumn{3}{|c|}{ Panamá } & \multicolumn{3}{|c|}{ Grenada } & \multicolumn{3}{|c|}{ Bermuda } \\
\hline & & $\mathrm{D}$ & I & $\mathrm{S}$ & $\mathrm{D}$ & I & $\mathrm{S}$ & $\mathrm{D}$ & I & $\mathrm{S}$ & $D^{*}$ & $\mathrm{I}^{*}$ & $\mathrm{~S}^{*}$ & $\mathrm{D}$ & I & $\mathrm{S}$ & $\mathrm{D}$ & I & $\mathrm{S}$ \\
\hline Cayman & $\begin{array}{l}\mathrm{D}(\mathrm{OTH}) \\
\mathrm{I}(\mathrm{OTH}) \\
\mathrm{S}(\mathrm{GAN})\end{array}$ & & & & & & & & & & & & & & & & & & \\
\hline Puerto Rico & $\begin{array}{l}\mathrm{D}(\mathrm{ASP}) \\
\mathrm{I}(\mathrm{OTH}) \\
\mathrm{S}(\mathrm{OTH})\end{array}$ & & & & & & & & & & & & & & & & & & \\
\hline Curaçao & $\begin{array}{l}\mathrm{D}(\mathrm{OTH}) \\
\mathrm{I}(\mathrm{GAN}) \\
\mathrm{S}(\mathrm{OTH})\end{array}$ & & & & & & & & & & & & & & & & & & \\
\hline Panamá & $\begin{array}{l}\mathrm{D}^{*} \\
\mathrm{I}^{*} \\
\mathrm{~S}^{*}\end{array}$ & & & & & & & & & & & & & & & & & & \\
\hline Grenada & $\begin{array}{l}\mathrm{D}(\mathrm{OTH}) \\
\mathrm{I}(\mathrm{OTH}) \\
\mathrm{S}(\mathrm{ASP})\end{array}$ & & & & & & & & & & & & & & & & & & \\
\hline Bermuda & $\begin{array}{l}\mathrm{D}(\mathrm{ASP}) \\
\mathrm{I}(\mathrm{OTH}) \\
\mathrm{S}(\mathrm{OTH})\end{array}$ & & & & & & & & & & & & & & & & & & \\
\hline
\end{tabular}

lence at the coral community level in many localities. This needs further confirmation, however.

Community-level disease prevalence was highly variable across reef sites as reported by Weil et al. (2002), with substantial variability overall; spatial patterns of coral disease prevalence were not consistent across habitats and reefs indicating a patchy distribution. The patchiness of coral diseases has often been observed (Bruckner \& Bruckner 1997a,b, 2006, Weil et al. 2002, Bruno et al. 2003, 2007) but not thoroughly discussed. In Curaçao, coral disease prevalence was higher at Habitat Hotel (7.4\%) compared with Sea Aquarium (4.5\%); and in Puerto Rico, the prevalence was $67 \%$ higher in Culebrita $(10.4 \%)$ compared to Guánica $(3.5 \%)$. Such high variability in prevalence and its patchy distribution in space within reefs and countries might be a consequence of (1) the abundance and spatial distribution of colonies of the different susceptible coral species, (2) variability in environmental conditions, and (3) the availability of potential pathogens in the area.

The spatial distribution of widespread diseases such as WP-II, BBD and DSD is clumped rather than uniform or random within particular reefs (Borger 2003). The patterns of spatial distribution and the abundance and diversity of susceptible hosts must affect the patterns of distribution and abundance of coral diseases (Ward et al. 2006, Bruno et al. 2007). It is also possible that slight variations in environmental parameters or specific microenvironments (i.e. micro-scale variation of temperature, nutrients, salinity, $\mathrm{pH}$, light) that normally occur in coral reefs (Kuta \& Richardson 2002) promote patchy or irregularly distributed infections over a reef community. The role of the physicochemical environment as a factor controlling coral diseases has been shown for widespread diseases such as BBD (Kuta \& Richardson 1996, 2002, Bruckner \& Bruckner 1997a,b), WP-II (Richardson et al. 1998a) and more recently for DSD (Gil-Agudelo \& Garzón-Ferreira 2001). The severity of diseases/syndromes such as YBD, BBD and ASP has been linked to increases in nutrient concentration, low water quality and high temperature (Bruckner \& Bruckner 1997a, Kim \& Harvell 2002, Bruno et al. 2003, Cervino et al. 2004, Weil et al. 2006, Harvell et al. 2007).

Epizootic events on the other hand may reach 15 to $40 \%$ infection rates at the coral community level (Bruckner \& Bruckner 1997b, 2006, Cróquer et al. 2003, Richardson \& Voss 2005) and between 20 and $80 \%$ within populations of the more susceptible spe- 


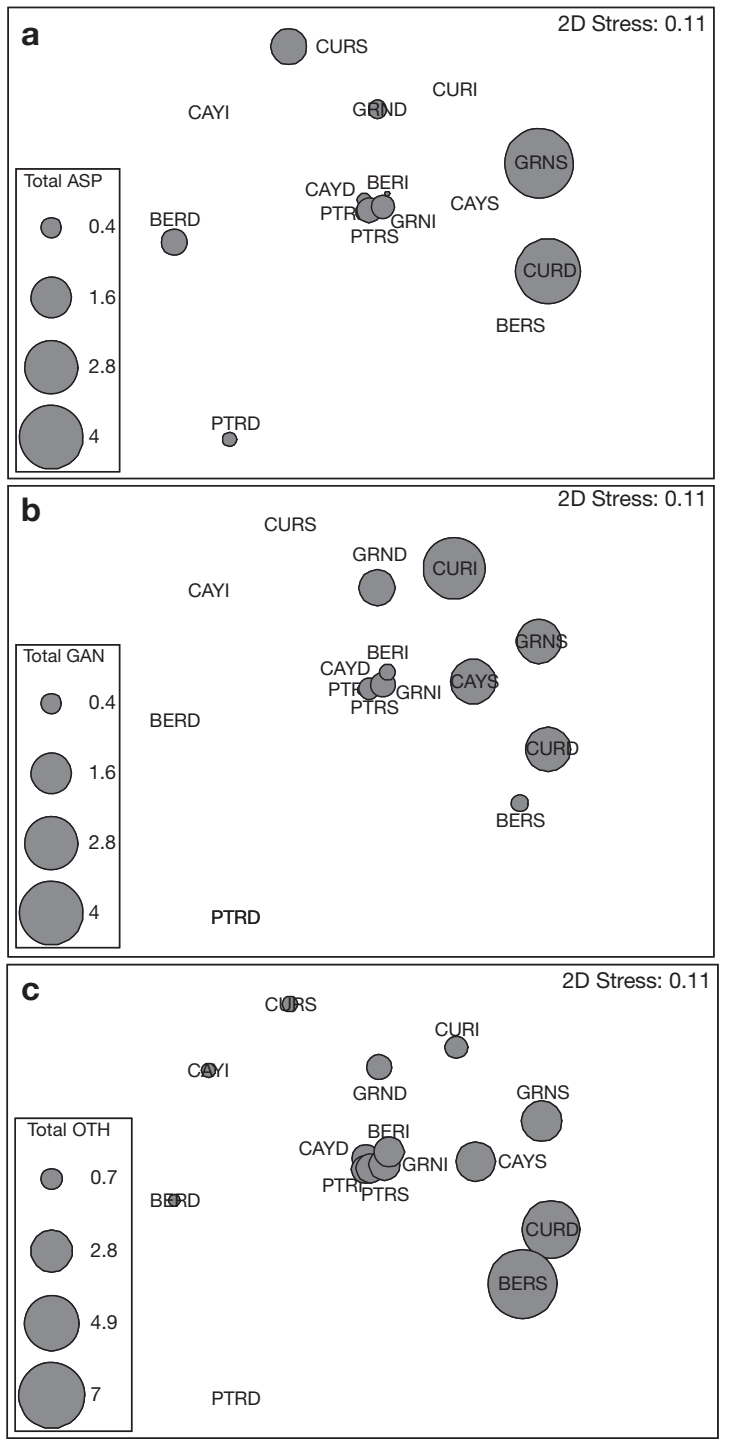

Fig. 5. Non-metric multidimensional diagram (NMDS) based on Bray-Curtis dissimilarities showing mean prevalence $(\log [x+1])$ of major octocoral diseases: (a) aspergillosis (ASP), (b) growth anomalies (GAN), and (c) other undescribed syndromes (compromise-health problems). Bubbles are mean prevalence of octocoral diseases. Country abbreviations as in Table 1, suffixed with the depth-related habitat $(\mathrm{S}=$ shallow, $\mathrm{I}=$ intermediate, $\mathrm{D}=$ deep) (e.g. CURS $=$ Curaçao Shallow $)$

cies such as Acropora spp. and Montastraea spp. (Gladfelter 1982, Richardson 1998, Richardson et al. 1998a,b, Santavy et al. 1999, Bruckner \& Bruckner 2006). Similarly to Weil et al. (2002), no widespread epizootic events were recorded during our surveys; however, local WP-II epizootic events were observed in Culebrita and in La Parguera (Puerto Rico), and were reported for the Virgin Islands (Miller et al. 2006) right after the bleaching event of 2005. White plague epizootics have been recurrent events at intermediate and deep habitats in several reefs off La Parguera since 2003 (E. Weil unpubl. data). Similarly, prevalence of YBD in populations of Montastraea spp. reached epizootic levels several years ago and have been steadily increasing for the last $10 \mathrm{yr}$ in several reefs off La Parguera (Harvell et al. 2009, E. Weil unpubl. data). The high variability in disease prevalence, even at lower spatial scales within reefs, and the characteristic patchy distribution pattern of epizootic events further complicates simple explanations as to the potential biological and/or environmental causes. The patchiness in disease distribution produces high variability among replicates at different spatial scales (belt-transects, habitats, reefs, countries or regions), increasing the variances and reducing statistical resolution, sometimes limiting interpretation of results. This is an important consideration when planning local or geographic surveys.

Bleaching events and high water temperatures have been proposed as potential factors influencing the emergence and development of coral diseases. Prolonged warmer periods might promote infections by affecting the mechanisms of host resistance and/or enhancing the virulence of pathogens (Harvell et al. 2002, 2007, Rosenberg \& Ben-Haim 2002). The level of temperature stress that could affect host or pathogen populations might be species- and/or location-specific, and the development of diseases in individual colonies and/or population epizootic events probably depend on the combination of several factors, including the physiological status of host populations, environmental stressors and the presence of potential pathogens. During 2005, Bermudian reefs were not affected by the bleaching event and unlike many other reefs in the Caribbean, high-temperature stress was absent during the summer and fall; nevertheless, some of the highest prevalence values for BBD and YBD were found here. Changes in water temperature are narrower and water remains warmer for longer periods near the tropics than at the northernmost reef sites (Bermuda) where temperature changes are broader due to seasonal variability. A reduction in the temperature difference between winter and summer (warmer winters for example) might be enough to keep infections active and to enhance spread of disease within populations and communities. Bacterial bleaching provides a good example of how coral pathogens (i.e. Vibrio shiloi and $V$. corallitycus) become more virulent whilst host resistance (i.e. Oculina patagonica and Pocillopora damicornis) is compromised as temperature increases (BenHaim et al. 1999, Banin et al. 2000, 2001a,b, Ben-Haim \& Rosenberg 2002). In the southern Caribbean, WP-II epizootics were reported in some localities only right after the intensive 2005 bleaching (Miller et al. 2006, E. Weil unpubl. data). 
The overall prevalence of BBD was an order of magnitude higher in shallow environments compared to deep habitats. However, this trend was not observed at all sites (i.e. there was a significant interaction between reef sites and habitats) but was similar to previous reports, and is related to the light-dependence of the BBD-bacterial consortium (Richardson \& Kuta 2003). Other diseases such as DSD and YBD were 6 times more prevalent at intermediate and deep habitats $(8$ to $18 \mathrm{~m}$ ) than in shallower depths, where prevalence did not exceed $0.1 \%$, and similarly to BBD, this pattern was not consistent among all sites. The occurrence of YBD and DSD seemed to be correlated with the distribution and abundances of susceptible species (Montastraea faveolata and M. franksi for YBD and Siderastrea siderea and Stephanochoenia intersepta for DSD), which had higher abundances at intermediate and deep environments (data not shown); however, this hypothesis needs to be further tested. Ciliates were 5 to 7 times more prevalent in southern countries (Curaçao and Panamá); they were found affecting coral colonies in both of our surveyed sites in both countries: Habitat Hotel ( 2.4\%), and Sea Aquarium in Curaçao $(0.3 \%)$, and Cayo Roldán (0.4\%) and Isla Colón $(0.9 \%)$ in Panamá. Cróquer et al. $(2006 a, b)$ found the protozoan in 25 coral species with a prevalence that varied between 0.2 and $2.5 \%$ in several reef localities of Venezuela, Puerto Rico, México and Panamá, and we have observed CCI problems in reefs of Grenada and the Caymans. Their apparent opportunistic behavior and the co-occurrence on colonies already diseased, might explain the low prevalence or absence in many reefs.

The low coral community-level disease prevalence reported here and in other studies (see reviews by Sutherland et al. 2004 and Weil 2004) can be explained by the fact that many common coral species were rarely affected by diseases (i.e. Madracis spp., Porites spp., Agaricia spp., Mycetophyllia spp.). If the total number of healthy, non-susceptible colonies greatly exceeded the total number of susceptible colonies affected by each particular disease then the impact and significance of local epizootics might be diluted when community level approaches are used in coral reefs with a high diversity and abundance of colonies (Cróquer \& Weil 2009). Even though wide host ranges have been reported for some of the most virulent coral diseases (Dustan 1977, 1987, Richardson 1998, Green \& Bruckner 2000, Weil et al. 2002, Sutherland et al. 2004, Weil 2004), all host species are not usually affected at the same time, or with the same intensity, even in wide-spread epizootics. In most epizootic events of WP-II and YBD for example, less than 25\% and $35 \%$ of the total number of species respectively reported to be susceptible to these diseases are affected. Presence of pathogens have not been tested in all the potential hosts reported, and only the similar signs observed in the different taxa have been used to indicate the susceptibility of that species to the disease. In many cases, only one or very few specimens have been observed with signs; therefore, host ranges for the most important diseases in the region (WP-II, YBD, DSD) should be re-evaluated pathologically and checked in the field on a continuous basis. Furthermore, host ranges of coral diseases should presumably decrease as pathogens become more host-specific with time (Weil 2004).

Coral diseases are mainly affecting the major reefbuilding species of the Caribbean (Weil et al. 2006) producing important negative impacts on populations and reef communities (Aronson et al. 1998, Richardson 1998, Richardson et al. 1998a,b, Aronson \& Precht 2001, Harvell et al. 2004, Richardson \& Voss 2005, Bruckner \& Bruckner 2006, Miller et al. 2006). A new problem observed in our surveys is that many colonies of these species (i.e. Montastraea, Colpophyllia, Diploria) were simultaneously affected by 2 or more infectious diseases/syndromes (WP-II, YBD, DSD, CCI) and bleaching. The significance of this regional trend needs to be further evaluated, but if the frequency of multiple diseases affecting single colonies keeps increasing, tissue mortality rates will increase and colony survivorship will decrease significantly. Populations of the major reef building species could then decline even faster, bringing their densities to critical low values in the near future, affecting their potential for recovery in many localities.

Octocoral diseases were 4 times more prevalent $(\sim 8 \%)$ than scleractinian coral diseases, with aspergillosis showing low average prevalence at all spatial scales $(2.06 \%)$, and other unknown syndromes and compromise-health problems contributing up to $75 \%$ of the overall disease prevalence in this group. The low prevalence of ASP observed in our surveys across the Caribbean in 2005 contrasts significantly with previous reports in which its prevalence ranged from 5 to $30 \%$ (Weil et al. 2002), but agrees with recent observations that ASP prevalence has been decreasing in many reef localities around the Caribbean (Kim \& Harvell 2004, Ward et al. 2006). The increasing response of different mechanisms of resistance against ASP (e.g. production of sclerites, antifungal and antibacterial compounds) in Gorgonia ventalina, the main species affected, a decrease in pathogen virulence, or a combination of these could explain the general regional decline in ASP prevalence (Kim et al. 1997, 2000a,b, Smith et al. 1998, Dube et al. 2002, Kim \& Harvell 2004, Mullen et al. 2004). Whether these resistance mechanisms could become more efficient in repelling the fungus as the interactions between sus- 
ceptible hosts and pathogen become more frequent remains to be investigated.

Compromise-health problems (unknown syndromes) affecting octocorals were 4 times more prevalent in the octocoral community (2.8 to $4.6 \%$ ) than unknown syndromes affecting scleractinian corals (0.3 to $0.8 \%$ ). This suggests that new octocorals diseases/syndromes might be emerging and becoming more frequent and prevalent. Octocorals and other important reef organisms have been overlooked in most disease monitoring programs and they are overall, poorly studied (Weil 2004). Aspergillosis is the most common problem (mainly affecting Gorgonia spp.) that has consistently been monitored. At least another 6 common and widespread octocoral species have been shown to be susceptible to ASP (Smith \& Weil 2004) and these too, need to be monitored regularly. The crustose octocoral Erythropodium caribbaeorum has been affected by an undescribed disease problem in most reefs of the Caribbean, specially after the bleaching event in 2005 when most colonies were totally bleached for an extended time (authors' unpubl. data).

Crustose coralline white syndrome (CCWS) is affecting significant numbers of at least one abundant crustose coralline algae (Neogoniolithon accretun) (Ballantine et al. 2005), an important reef building and cementing organism, across the wider Caribbean (data not shown). Many species of sponges (e.g. Xetospongia muta, Cliona tenuis, Anthosigmella varians) and the common shallow water zoanthyd Palythoa caribaeorum, are also showing signs of infections, with wide areas of rapidly decaying tissue, in many reef localities across the Caribbean (Weil et al. 2006, authors' unpubl. data).

Community level approaches are needed to monitor overall health of the coral/octocoral community, the changes in proportions of species affected, and whether more taxa are becoming susceptible to disease over time, and how diseases affect different components, or the community as a whole. To better understand what the actual and/or potential impact of particular diseases is on important reef species, it is better to characterize the etiology and epidemiology of the different diseases and other health problems at the population and species level, avoiding the 'noise' introduced in the calculations by all the species that are not susceptible to diseases at that particular point in time (Cróquer \& Weil 2009).

Overall, our results show that coral and octocoral diseases continue to be widespread across the wider Caribbean with low, but highly variable average community-level prevalence of individual diseases and total diseases. Prevalence of coral and octocoral diseases was highly variable at different spatial scales due to the patchy distribution of diseases within habi- tats, reefs, countries and regions. While some diseases such as BBD were restricted to shallow habitats, others (YBD and DSD) tended to be more prevalent at intermediate to deep habitats, however, this trend was not consistent among all sites and countries. This patchy distribution depends on the combination of different factors such as (1) host population distribution and abundances, (2) environmental factors and (3) presence of potential pathogens. WP-II showed a wide depth distribution, possibly related to the pathogen(s) tolerance to different environmental conditions and the abundances and distribution of multiple host species. Coral disease prevalence and susceptible coral species appeared to co-vary, but this needs to be tested. Analysis at the community level usually provides low disease prevalence values due to the wide range of species that are seldom affected by diseases; the interpretation and use of this information should be framed within community-level questions only. Octocoral diseases were on average 2 to 4 times more prevalent than scleractinian coral diseases, mostly due to uncharacterized syndromes other than ASP, which showed significantly lower prevalence values than in 1999. More research must focus on the other important biological groups that conform the coral reef community. Coral and octocorals disease monitoring programs should incorporate disease surveys at different spatial scales to assess and understand the levels of variability. This information is important for the design and implementation of better management strategies. We have added one more reef in each country and our surveys of the same localities will continue every year until 2009 providing a long term database and information on the temporal variability of the different diseases in the region.

Acknowledgements. Funding for this study was provided by the Global Environment Facility (GEF) and World Bank Coral Reef Targeted Research and Capacity Building program through the Coral Disease Working Group. Partial funding was provided by NOAA-CRES (project no. NA170p2919), and the Department of Natural Resources of Puerto Rico. We thank Steve Pointek and the Curaçao Sea Aquarium, The Habitat dive shop in Curaçao; Clare Morrall (Department of Biology, University of Grenada) and Devotion 2 Ocean dive shop in Grenada; Hector Guzmán, Carlos Guevara and the Smithsonian Tropical Research Institute in Panamá; Jack Ward, Kathryn Coates, Sarah Manuel and Captain Anson Nash of the Department of Conservation Services in Bermuda; and Gina Fairbanks, Croy McCoy and the Department of the Environment in Grand Cayman, for their kind welcome and outstanding logistical support. Edwin Hernandez, Miguel Canals, Carlos Pacheco of the Department of Natural Resources, and the Department of Marine Sciences, University of Puerto Rico, provided logistical support in Puerto Rico. Katie Flynn and Emmanuel Irizarry provided valuable field help. John Bruno and 3 anonymous reviewers provided useful comments on the manuscript. 


\section{LITERATURE CITED}

Anderson MJ (2001) A new method for non-parametric analysis of variance. Austral Ecol 26:32-46

Aronson RB, Precht WF (2001) White-band diseases and the changing face of Caribbean coral reefs. Hydrobiologia 460:25-38

Aronson RB, Precht WF, Macintyre IG (1998) Extrinsic control of species replacement on a Holocene reef in Belize: the role of coral disease. Coral Reefs 17:223-230

Aronson RB, Precht WF, Toscano MA, Koltes KH (2002) The 1998 bleaching event and its aftermath on a coral reef in Belize. Mar Biol 141:435-447

Ballantine DL, Weil E, Ruiz H (2005) Coralline white band syndrome, a coralline algal affliction in the tropical Atlantic. Coral Reefs 24:117

Banin E, Israely T, Kushmaro A, Loya Y, Orr E, Rosenberg E (2000) Penetration of the coral-bleaching bacterium Vibrio shiloi into Oculina patagonica. Appl Environ Microbiol 66: 3031-3036

Banin E, Khare SK, Naider F, Rosenberg E (2001a) Prolinerich peptide from the coral pathogen Vibrio shiloi that inhibits photosynthesis of zooxanthellae. Appl Environ Microbiol 67:1536-1541

Banin E, Israely T, Fine M, Loya Y, Rosenberg E (2001b) Role of endosymbiotic zooxanthellae and coral mucus in the adhesion of the coral-bleaching pathogen Vibrio shiloi to its host. FEMS Microbiol Lett 199:33-37

Ben-Haim Y, Rosenberg E (2002) A novel Vibrio sp. pathogen of the coral Pocillopora damicornis. Mar Biol 141:47-55

Ben-Haim Y, Banin E, Kushmaro A, Loya Y, Rosenberg E (1999) Inhibition of photosynthesis and bleaching of zoo-xanthellae by the coral Vibrio shiloi. Environ Microbiol 1: 223-229

Borger JL (2003) Three scleractinian coral diseases in Dominica, West Indies: distribution, infection patterns and contribution to coral tissue mortality. Rev Biol Trop 51: 25-38

Bruckner AW, Bruckner RJ (1997a) Outbreak of coral disease in Puerto Rico. Coral Reefs 16:260

Bruckner AW, Bruckner RJ (1997b) The persistence of black band disease in Jamaica: impact on community structure. Proc 8th Int Coral Reef Symp, Panama 1:601-606

Bruckner AW, Bruckner RJ (2006) Consequences of yellow band disease (YBD) on Montastraea annularis (species complex) populations on remote reefs off Mona Island, Puerto Rico. Dis Aquat Org 69:67-73

Bruno JF, Peters LE, Harvell CD, Hettinger A (2003) Nutrient enrichment can increase the severity of coral diseases. Ecol Lett 6:1056-1061

Bruno JF, Selig ER, Casey KS, Page CA and others (2007) Thermal stress and coral cover as drivers of coral disease outbreaks. PLoS Biol 5:e124, doi:10.1371/journal.pbio. 0050124

Cervino JM, Hayes LH, Polson SW, Polson SC, Goreau TJ, Martinez RJ, Smith GW (2004) Relationship of Vibrio -species infection and elevated temperatures to yellow blotch/band disease in Caribbean corals. Appl Environ Microbiol 70:6855-6864

Clarke KR, Warwick RM (2001) Change in marine communities: an approach to statistical analysis and interpretation, 2nd edn. PRIMER-E, Plymouth

Cortés J (2003) Coral reefs of the Americas: an introduction to Latin American coral reefs. In: Cortés J (ed) Latin American coral reefs. Elsevier Science, Amsterdam, p 1-7

> Cróquer A, Weil E (2009) Spatial variability in distribution and prevalence of Caribbean scleractinian coral and octocoral diseases. II. Genera-level analysis. Dis Aquat Org 83:209-222
Cróquer A, Pauls SM, Zubillaga AL (2003) Coral disease outbreak in a coral reef at Los Roques National Park. Rev Biol Trop 51:39-45

> Cróquer A, Bastidas C, Lipscomb D (2006a) Folliculinid ciliates: A new threat to Caribbean corals? Dis Aquat Org 69:75-78

Cróquer A, Bastidas C, Lipscomb D, Rodríguez Martínez RE, Jordan-Dahlgren E, Guzmán HM (2006b) First report of folliculinid ciliates affecting Caribbean corals. Coral Reefs 25:187-191

> Dube D, Kim K, Alker AP, Harvell CD (2002) Size structure and geographic variation in chemical resistance of sea fan corals Gorgonia ventalina to a fungal pathogen. Mar Ecol Prog Ser 231:139-150

Dustan P (1977) Vitality of reef coral populations off Key Largo Florida: recruitment and mortality. Environ Geol 2: $51-58$

Dustan P (1987) Preliminary observations of the vitality of reef coral in San Salvador, Bahamas. In: Curran HA (ed) Proc Third Symp on Geol of the Bahamas. CCFL Bahamian Field Station, San Salvador, p 57-65

> García A, Cróquer A, Pauls SM (2003) El estatus de las enfermedades de corales escleractínidos en seis arrecifes del Parque Nacional Los Roques. Rev Biol Trop 51:173-180

Gil-Agudelo DL, Garzón-Ferreira J (2001) Spatial and seasonal variation of dark spots disease in coral communities of the Santa Marta area (Colombian Caribbean). Bull Mar Sci 69:619-629

Gladfelter WB (1982) White-band disease in Acropora palmata: implications for the structure and growth of shallow reefs. Bull Mar Sci 32:639-643

- Green EP, Bruckner AW (2000) The significance of coral disease epizootiology for coral reef conservation. Biol Conserv 96:347-361

Harvell CD, Kim K, Burkholder JM, Colwell RR and others (1999) Emerging marine diseases - climate links and anthropogenic factors. Science 285:1505-1510

> Harvell CD, Mitchell CE, Ward JR, Altizer S, Dobson AP, Ostfeld RS, Samuel MD (2002) Climate warming and disease risk for terrestrial and marine biota. Science 296: 2158-2162

Harvell CD, Aronson R, Baron N, Connell J and others (2004) The rising tide of ocean diseases: unsolved problems and research priorities. Front Ecol Environ 2:375-382

Harvell CD, Markel S, Jordan-Dahlgren E, Raimundo L and others (2007) Coral disease, environmental drivers and the balance between coral and microbial associates. Oceanography (Wash DC) 20:36-59

Harvell CD, Altizer S, Cattadori IM, Harrington L, Weil E (2009) Climate change and wildlife diseases: When does the host matter the most? Ecology (in press)

Kaczmarsky LT, Draud M, Williams B (2005) Is there a relationship between proximity to sewage effluent and the prevalence of coral disease? Caribb J Sci 41(1):124-137

Kim K, Harvell CD (2002) Aspergillosis of sea fan corals: disease dynamics in the Florida Keys. In: Porter JW, Porter KG (eds) The Everglades Florida Bay and coral reefs of the Florida Keys: an ecosystem sourcebook. CRC Press, New York, p 813-824

Kim K, Harvell CD (2004) The rise and fall of a six year coralfungal epizootic. Am Nat 164:S52-S53

Kim K, Harvell CD, Smith GW (1997) Mechanisms of sea fan resistance to a fungal epidemic. I. Role of sclerites. Am Zool 37:132A

Kim K, Harvell CD, Kim PD, Smith GW, Merkel SM (2000a) Fungal disease resistance of Caribbean sea fan corals (Gorgonia spp). Mar Biol 136:259-267 
Kim K, Kim PD, Alker AP, Harvell CD (2000b) Chemical resistance of gorgonian corals against fungal infections. Mar Biol 137:393-401

Kuta KG, Richardson LL (1996) Abundance and distribution of black band disease on coral reefs in the northern Florida Keys. Coral Reefs 15:219-223

Kuta KG, Richardson LL (2002) Ecological aspects of black band disease of corals: relationships between disease incidence and environmental factors. Coral Reefs 21:393-398

Lang JC (ed) (2003) Status of coral reefs. I. The western Atlantic: result of initial surveys, Atlantic and Gulf Rapid Reef Assessment (AGGRA) Program. Atoll Res Bull 496

McCallum H, Harvell CD, Dobson A (2003) Rates of spread of marine pathogens. Ecol Lett 6:1062-1067

McClanahan TR, Weil E, Cortés J, Baird A, Ateweberhan M (2009) Consequences of coral bleaching for sessile organisms. In: van Oppen M, Lough J (eds) Coral bleaching: patterns, processes, causes and consequences. Springer Ecological Studies, Berlin, p 121-138

Miller J, Waara R, Muller E, Rogers C (2006) Coral bleaching and disease combine to cause extensive mortality on corals reefs in US Virgin Islands. Coral Reefs 25:418

Mullen K, Peters E, Harvell CD (2004) Coral resistance to disease. In: Rosenberg E, Loya Y (eds) Coral health and disease. Springer-Verlag, Berlin, p 377-395

Richardson LL (1998) Coral diseases: What is really known? Trends Ecol Evol 13:438-443

Richardson LR, Kuta KG (2003) Ecological physiology of the black band disease cyanobacterium Phormidium corallyticum. FEMS Microbiol Ecol 43:287-298

Richardson LL, Voss JD (2005) Changes in a coral population of reef of the northern Florida keys following a coral disease epizootic. Mar Ecol Prog Ser 297:147-156

Richardson LL, Goldberg WM, Carlton RG, Halas JC (1998a) Coral disease outbreak in the Florida Keys: plague type II. Rev Biol Trop 46:187-198

Richardson LL, Goldberg WM, Kuta KG, Aronson RB, and others (1998b) Florida's mystery coral killer identified. Nature 392:557-558

Richardson LL, Smith GW, Ritchie KB, Carlton RG (2001) Integrating microbiological microsensor molecular and physiologic techniques in the study of coral disease pathogenesis. Hydrobiologia 460:71-89

Editorial responsibility: John Austin,

Oldendorf/Luhe, Germany
Rosenberg E, Ben-Haim Y (2002) Microbial diseases of corals and global warning. Environ Microbiol 4:318-326

Santavy DL, Peters EC, Quirolo C, Porter JW, Bianchi CN (1999) Yellow-blotch disease outbreak on reefs of the San Blas Islands, Panama. Coral Reefs 18:97

> Santavy DL, Summers JK, Engle VD, Harwell LC (2005) The condition of coral reefs in south Florida (2000) using coral disease and bleaching as indicators. Environ Monit Assess 100:129-152

Smith GW, Weil E (2004) Aspergillosis of gorgonians. In: Rosenberg E, Loya Y (eds) Coral health and disease. Springer-Verlag, Berlin, p 279-286

Smith GW, Harvell CD, Kim K (1998) Response of sea fans to infection with Aspergillus sp. (Fungi). Rev Biol Trop 46: 205-208

> Sutherland KP, Porter JW, Torres C (2004) Disease and immunity in zooxanthellate Caribbean corals. Mar Ecol Prog Ser 266:273-302

Underwood AJ (1999) Experiments in ecology, their logical design and interpretation using analysis of variance. Cambridge University Press, Cambridge

- Ward JR, Lafferty K (2004) The elusive baseline of marine disease: Are diseases in ocean ecosystems increasing? PLoS Biol 2(4):e120, doi:10.1371/journal.pbio.0020120

> Ward JR, Rypien KL, Bruno JF, Harvell CD and others (2006) Coral diversity and disease in Mexico. Dis Aquat Org 69: 23-31

Weil E (2004) Coral reef diseases in the wider Caribbean. In: Rosenberg E, Loya Y (eds) Coral health and disease. Springer-Verlag, Berlin, p 35-67

Weil E, Urreiztieta I, Garzón-Ferreira J (2002) Geographic variability in the incidence of coral and octocoral diseases in the wider Caribbean. Proc 9th Int Coral Reef Symp Bali 2:1231-1237

Weil E, Smith GW, Gil-Agudelo DL (2006) Status and progress in coral reef disease research. Dis Aquat Org 69: $1-7$

Williams EH, Bunkley-Williams L (1990) The world-wide coral reef bleaching cycle and related sources of coral mortality. Atoll Res Bull 335:1-71

Willis BL, Page CA, Dindsdale EA (2004) Coral disease in the Great Barrier Reef. In: Rosenberg E, Loya Y (eds) Coral health and disease. Springer-Verlag, Berlin, p 69-104

Submitted: October 24, 2007; Accepted: November 5, 2008

Proofs received from author(s): February 19, 2009 